\title{
Reflections on Indirect Speech Act Theory and Its Application in Teaching English Listening Comprehension
}

\author{
Bu-Han PAN \\ School of Foreign Languages, Huazhong Agricultural University, Wuhan 430070, Hubei, China \\ panbuhan@163.com
}

Keywords: Reflections, Indirect speech act, Listening comprehension.

\begin{abstract}
Searle's indirect speech act theory has been proved to be one of the most influential theories in pragmatics, and it also has a lot of useful implications in today's EFL teaching. In order to help students develop their linguistic competence, one good way is to teach indirect speech acts in the process of language skills training. This paper will first make a comprehensive review of indirect speech act theory, and then apply it into teaching English listening comprehension.
\end{abstract}

\section{Introduction}

The theory of indirect speech acts was put forward by the American philosopher of language John Searle (1969, 1975). It originated from Austin's (1962) theory, but made some revisions. One of Searle's contributions lies in his understanding of the importance of speech acts. He regards a speech act as a basic unit in social communication, yet not a word or a sentence. This means that his theory pays much attention to the functions rather than the forms of languages. This shift of focus also occurs in the field of English language teaching with the development of communicative language teaching in 1980s.

As time goes by, Searle's theory has been proved to be one of the most influential theories in pragmatics, and it also has a lot of useful implications in today's English language teaching. As a foreign language teacher, I pay much attention to the development of teaching methods, especially in the context of Mainland China. However, no matter what methods teachers use, teachers tend to realize that they should help students improve their communicative competence other than teach them forms of language (Hymes, 1972). Bachman (1990) believes that linguistic competence consists of organizational competence and pragmatic competence. In order to let students have full development of their linguistic competence, one good way is to help students understand some indirect speech acts and cultural differences between the source language and the target language. In order to achieve this educational goal, I will first try to make a comprehensive review of indirect speech act theory, and then apply it into the practice of listening comprehension teaching.

Widdowson (1978) believes that the ultimate goal of learning English is to use the language to communicate. Students' listening abilities directly influence their performances in interpersonal interactions. Thus, in order to help students develop their pragmatic competence in real communications, listening comprehension teaching has gained more and more attention from English teachers as well as educators. The latest version of College English Teaching Syllable was issued by the Ministry of Education in 2007, and revised teaching goals for listening and speaking are highlighted and emphasized in the syllable. Recent reform in CET (College English Test) has increased the weighting for the part of listening comprehension from $20 \%$ to $35 \%$.

However, in order to implement these policies into practice, teachers need to enhance their quality of teaching. In my opinion, teaching listening is to deal with some real language uses in our lives, thus some theories in pragmatics seem to be of great help to teaching practice. The focus of this reflective paper is to find out how indirect speech act theory can be used in teaching listening comprehension.

One major contribution of indirect speech act theory is that it goes beyond the extent of language knowledge and cares much about the language user's communicative competence. To introduce the 
theory to students not only can facilitate teaching listening comprehension, but also can push students to pay more attention to the functions and contextual meanings in language use.

\section{Austin's Speech Act Theory}

It all begins with Austin's (1962) distinction between two kinds of sentences: performatives and constatives. Austin argues that the uttering of a performative sentence is actually doing an action. Some typical verbs are used in the sentences, such as name, bet, promise, warn, etc. These verbs are called performative verbs. Later, when Austin tries to separate performatives from constatives, he realizes the difficulty in distinguishing them from apart. In fact, all sentences can be used to perform speech acts.

In order to explain in what sense to say something is to do something, Austin classifies three kinds of speech acts: 1) locutionary act-the movement of vocal organs to produce a stretch of meaningful sounds, 2) illocutionary act-the making of a statement, offer, promise, etc. to fulfill the purpose of speaking, and 3) perlocutionary act-the effects left on the audiences. The second speech act, i.e. illocutionary act, is the focus of Austin's research, because the illocution of an utterance is the speaker's communicative intention or the function it is intended to perform. In this sense, Austin's speech act theory is actually a theory of illocutionary acts. His previous research focus performatives then in fact belongs to a special group of illocutionary acts which are expressed explicitly.

\section{Searle's Indirect Speech Act Theory}

Searle continues his teacher's research on illocutionary acts, and finds that actually all the speech acts can be seen as illocutionary acts. He makes some revisions to Austin's felicity conditions and use new terms to classify felicity conditions into three: preparatory conditions, propositional content conditions and sincerity conditions (Searle, 1969). In Searle's opinion, felicity conditions are more than measures to see negatively whether speakers have gone wrong, but can be used positively as rules that speakers need to obey in order to create speech acts. Searle (1969) also suggests five basic categories of illocutionary acts as follows: assertives, directives, commisives, expressives, and declaratives.

In the study of felicity conditions, Searle finds some utterances which deliberately fail to fulfill the conditions for the speech act. However, these utterances tend to conduct another speech act whose felicity conditions have been satisfied. This means that with the same utterance the "speaker meaning" is different from the "literal meaning", and that is the reason why the utterance perform a speech act which is different from the one usually related to the "literal meaning" (He, 1997). Based on the above understanding, Searle (1975) defines an indirect speech act as an illocutionary act which "is performed indirectly by way of performing another." In summary, people often express ideas in an indirect way which leads to two illocutionary acts in the indirect utterance. The speech act related to the speaker meaning is called primary illocutionary act, while the act linked to the literal meaning is called secondary illocutionary act.

\section{Felicity Conditions}

In order to perform certain speech acts successfully, the speaker has to satisfy certain felicity conditions. Let's have a review of Searle's (1969) three categories of felicity conditions again: 1) Preparatory conditions-conditions that identify the particular circumstances and participants appropriate to performing a given illocutionary act. 2) Propositional content conditions-conditions that define the content of the utterance. 3) Sincerity conditions-conditions that involve the speaker's necessary belief, emotion and intention.

According to these principles, we can analyze the felicity conditions of a particular speech act. Take the speech act request as an example to show how A request $\mathrm{B}$ to do $\mathrm{C}$ : 1 ) Preparatory conditions-A has not done C; A believes that B can do C; B will not do C if he is not asked to. 2) 
Propositional content conditions-State the act C that B will perform. 3) Sincerity conditions-A really wants B to do C.

As to indirect speech acts, the analyses of their felicity conditions not only help us to identify indirect speech acts, but also lead us to the understanding of speaker meaning in the utterance. If an utterance violates the felicity conditions of literal-meaning speech act, it might have some implied meanings to it.

\section{Classification of Indirect Speech Acts}

Searle (1969) classified indirect speech acts into two categories: conventional and unconventional. Conventional indirect speech acts refer to those utterances with familiar and fixed expressions (Hu and Jiang, 2002). People take these indirect speech acts for granted and even fail to detect the illocutionary force in the literal meaning of utterances. Unconventional indirect speech acts are much more difficult to detect, so the hearer need to analyze the context, share some common knowledge with the speaker and have some basic reasoning abilities to figure out the indirect speech act. Searle (1979) has summarized some typical indirect directives which can be used in the conventional indirect speech acts.

\section{Its Relations with Other Pragmatic Theories}

People usually express their ideas indirectly for the purpose of politeness, since indirect utterances seem to be more gentle and more polite. Therefore, the use of indirect speech acts obeys the politeness principles. Face is a person's public self-image, and showing politeness means the awareness of another person's face (Yule, 1996). Leech's (1983) politeness principles explain why sometimes people deliberately violate the cooperative principles to express indirectly.

Indirect speech act theory is also closely related to Grice's cooperative principles. In the conversations, people may deliberately violate the cooperative principles so as to fulfill the implicature in the conversation. The similar situation occurs when indirect speech acts may violate the felicity conditions of the original act so as to fulfill the conditions of primary illocutionary act. In my opinion, indirect speech acts and cooperative principles are both useful tools to explore the "speaker meaning" in the utterances. In listening comprehension teaching, we may use both these tools to analyze implied meanings of some materials.

\section{Overview of Listening Comprehension Teaching}

Listening comprehension is not only one of the important language skills required to develop in second language learning, but also plays an important role in China's foreign language teaching. Researchers (Rivers, 1981; Morley, 1991) estimate that we listen twice as much as we speak, four times as much as we read, and five times as much as we write, which demonstrates what an important role listening comprehension plays in foreign language learning and teaching. Moreover, with the increasing needs of communication between people from different countries, it also has great practical significance in promoting the effective communication between people.

However, traditional approaches of listening comprehension teaching only stay at language itself. It pays major attention to the forms of language like pronunciation, vocabulary or grammar, etc., and thus ignores the contents and communicative functions of the language. Listening comprehension exercises depend too much on students' ability of memory. Sometimes students just passively take down what they hear without even understanding the contents. For the majority of students, listening comprehension course is considered as the most bothering and most difficult one for them. When students met the indirect utterances in the real communication, they would probably fail to understand them. In today's English listening tests, more and more indirect speech acts are used with an indication of the question types like "what does the speaker imply?” and "what can we infer from 
the conversation?" In order for the students to have a better understanding of the indirect utterances in listening tasks, we can teach students the methods to analyze indirect speech acts in dialogues.

With the development of communicative teaching, listening comprehension should be considered as an active and dynamic process of listening (paying attention to utterances) and comprehending (trying to interpret the indirect pragmatic meanings from something we hear). Therefore, how to "listen to" the indirect utterances appears to be one of the most crucial barriers which influence students' listening comprehension. To comprehend successfully through listening to spoken language, listeners need to be able to work out the speakers' meanings when they use particular words in particular ways on particular occasions, such as to understand speakers' intentions, to differentiate speech act meaning, to evaluate the intensity of speakers' meanings, to recognize facetious behaviors and respond appropriately, and so forth, rather than simply to understand the literal meanings of texts. In order to realize the above teaching goals, we should not only explain the indirect speech act theory to our students, but also help them in analyzing indirect utterances by using the theory. What's more, we should also encourage our students to become conscious of indirect speech acts in their daily interactions.

\section{Example-based Analyses of Indirect Speech Acts in Textbooks and CET Examination Papers}

This is sample of analysis to show that the phenomenon of speech acts is very common in our listening materials. Some examples are chosen here from textbooks and CET test papers to show how indirect speech acts are used in short dialogues. Students will also be encouraged to analyze examples by the theory.

Example 1:

M: What would you like for dessert? I think I'll have apple-pie and ice-cream.

W: The chocolate cake looks great, but I have to watch my weight. You go ahead and get yours.

Q: What would the woman most probably do?

The conversation may happen in a restaurant during the ordering time. The man asks the woman what kind of dessert she will order. The woman hesitates with the utterance of an assertion. She does not answer the man's question directly, but perform an indirect speech act of refusal.

Example 2:

M: Would you like to go on a picnic with me tomorrow?

W: I'm sorry. I have an appointment with Dr. Smith tomorrow morning.

Q: What does the woman mean?

This dialogue is similar to the first example. In order to be gentle and polite, the woman does not answer the man's question directly. On the surface, she speaks with an assertion, but actually she performs an indirect speech act of refusal.

Example 3:

S: Do I have to take the test?

T: Do you want to graduate?

Q: What does the teacher mean?

Instead of answering the student's simple question yes or no, the teacher raises another question back. The implied meaning here is that if the student does not take the test, he will have some trouble in graduation. The teacher's answer is more like a warning towards the student, definitely not just a question.

Example 4:

M: Can you pass me the potato chips?

W: Don't you think you've had enough?

Q: What does the woman mean?

At the beginning of the dialogue, the man uses a question to perform an indirect speech act of request. The woman replies with another question which embraces an indirect speech act of criticism. Maybe the man is already overweight, but still pays little attention to his unhealthy diet. 


\section{Methods to Improve Students’ Performance in English Listening Comprehension}

\section{Identification of Indirect Speech Acts}

Surely, teachers should help students to identify indirect speech acts. Although factors like the contexts, the manner of the speaker and the common background knowledge, reasoning ability among people may help us to recognize indirect speech acts, some textual features may also help. Tserdanelis and Wang (2004) provide several ways determine indirect speech acts as the followings: 1) we can check the utterance to see if there is a performative verb in the sentence, because performative verbs can only be used in direct speech acts. 2) If you cannot find performative verbs in the utterance, you can check the sentence form. Because certain sentence form is usually used to perform certain speech act, but fails to do so if it is an indirect speech act. 3) If the felicity conditions of the speech acts of literal meaning are violated, while not violated for the implied meaning, an indirect speech act is used. 4) We can imagine a context for the utterance to see whether people respond to it normally. If listeners respond with an unusual answer, an indirect speech act might be used.

Upon analyses of examples of indirect speech acts in listening materials, teachers should help students to summarize some methods of identifying indirect speech acts. Until the students can identify and analyze indirect speech acts by themselves, their understanding of the functions of language will be deepened.

\section{Teacher Talk}

In order to let student pay more attention to the use of indirect speech acts and language functions, teachers should also pay attention to their language use in the classroom. For indirect speech acts, Searle (1979) has summarized some fixed expressions and structures that may be used in conventional indirect speech acts. To improve the quality of teacher talk in the classroom, we may make a best use of these expressions and structures. For example, if a teacher wants to give some suggestions to a student, the following sentence structures can be used to perform indirect speech acts: should we be thinking about..., what about..., why not..., what if..., why don't you..., what would you say to....

\section{Inferring Illocutionary Force}

In a particular speech event, the role played by the language is largely constrained by the social conventions. One can not only draw information from the linguistic context, but also from the functions assigned to the utterances on the basis of situation. Thus in a classroom the following exchange may have a natural interpretation divergent from the context of what is said. e. g. Teacher: "What are you laughing at?" Student: "Nothing.” According to the context it was reasonable to think that the teacher was asking the student why he was laughing, but since it was in a classroom, there will be a different interpretation. In accordance with social conventions, laughing in the classroom is forbidden. Therefore the teacher was using the question to stop the student from laughing on.

We can have "Tom is like a fish" as another example. As an idiom, that somebody is like a fish can only mean that somebody can drink a lot of wine, especially when the setting is a banquet and the topic is drinking. When the setting is shifted to a swimming pool and the topic is changed to swimming, the same sentence can only be regarded as a compliment to Tom's swimming skill. In view of speech acts' dependence on setting, the setting of speech events should be emphasized in our teaching. When we are citing examples for our students, we should draw their attention to the dependence of language use on its setting.

\section{Conclusion}

To reflect on indirect speech act theory, I am aware of its potential applications in English language teaching. In my opinion, indirect speech acts attract us to pay more attention to the functions of English, thus direct students on the right path of language learning. Although some linguists argue 
that nearly all the speech acts are indirect to some degree and Searle's introduction of the new term is unnecessary (Levinson, 1983; Thomas, 1995), I still hold that the distinction between direct and indirect speech acts is worthwhile. The indirect speech act theory at least provides us a new perspective to observe and understand the functions of English.

\section{References}

[1] J. L. Austin. How to Do Things with Words. New York: Oxford University Press, 1962.

[2] L. F. Bachman. Fundamental Considerations in Language Testing. New York: Oxford University Press, 1990.

[3] Z. R. He. Pragmatics and English Learning. Shanghai: Shanghai Foreign Language Education Press, 1997.

[4] Z. L. Hu \& W. Q. Jiang. Linguistics: An Advanced Course Book. Beijing: Peking University Press, 2002.

[5] D. Hymes. On Communicative Competence. In Pride. J. B. and Holmes, J. (Eds.), Sociolinguistics. London: Penguin, 1972.

[6] W. Q. Jiang. Pragmatics: Theories and Applications. Beijing: Beijing University Press, 2000.

[7] G. Leech. Principles of Pragmatics. London: Longman, 1983.

[8] S. C. Levinson. Pragmatics. Cambridge University Press, 1983.

[9] J. Morley. Listening Comprehension in Second or Foreign Instruction. Cambridge: Cambridge University Press, 1991.

[10] W. Rivers. Teaching Foreign Language Skills. Chicago: Chicago University Press, 1981.

[11] J. R. Searle. Speech Acts: An Essay in the Philosophy of Language. New York: Cambridge University Press, 1969.

[12] J. R. Searle. Indirect speech acts. In Cole, P. and Morgan, J. (Eds.), Syntax and Semantics. Vol. 3. Speech Acts. New York: Academic Press, 1975.

[13] J. R. Searle. Expression and Meaning: Studies in the Theory of Speech Acts. New York: Cambridge University Press, 1979.

[14] J. Thomas. Meaning in Interaction: An Introduction to Pragmatics. London: Longman, 1995.

[15] G. Tserdanelis \& W. Y. P. (Eds.). Language Files: Materials for an Introduction to Language and Linguistics (9th ed.). Columbus: The Ohio State University Press, 2004.

[16] G. Yule. The Study of Language. Cambridge: Cambridge University Press, 1996. 